DOI: 10.20472/IAC.2019.052.024

TSOGHIK GRIGORYAN

Higher Colleges of Technology, United Arab Emirates

JANICE COATS

Higher Colleges of Technology, United Arab Emirates

PAOLO ROSSETTI

Higher Colleges of Technology, United Arab Emirates

\title{
ESSENTIAL SKILLS FOR AT-RISK STUDENTS' ADVISING: ACTIVITY THEORY BASED ANALYSIS OF A PILOT STUDY
}

\begin{abstract}
:
First year bachelor students have a much higher level of responsibility than they experienced in foundations or high school. Students who do not manage their responsibilities well may experience failure in classes that can lower their self-concept and cause them to drop out of college altogether. For many of these students, the academic difficulty of the bachelor courses was compounded by a lack of student skills. To address this issue, the Academic Success Program (ASP) Coordinators at one of the tertiary level institutions in the United Arab Emirates presented an initiative to the management team to help codify the procedures for dealing with at-risk students. In this initiative, the ASP personnel met individually with the identified students twice with a two week interval, discussed the Essential Skills for College Students and worked with them to create individual learning plans to improve their skills. To keep the learning plan in focus, the students kept daily reflective journals for two weeks identifying the actions they took to improve their skills and met again the ASP personnel to discuss successes and further challenges that needed to be addressed. The analysis showed that when students reflect, the value of reflections stem from the ways through which learning is achieved, whether students are able to develop study skills through growth mind set and whether they are able to control the learning speed and style of interaction. So, from the ASP perspective in learning, control of learning can be achieved based on learner characteristics such as self-efficacy and self-regulation, which, as students' reflections showed, can successfully result in motivation and active learning.
\end{abstract}

\section{Keywords:}

Activity Theory, advising, at-risk students, essential skills, pilot study, reflective journals 


\section{Introduction}

The project was carried out in a tertiary level institution in the United Arab Emirates. In February 2018, there were 144 students in semester 3 who already had a GPA below 2.0. That means $30 \%$ of third semester students were already at risk. The Success Center personnel took the initiative of addressing the issue by looking into student skills through individual meetings, discussions and reflective journal entries. This report is a review of the information gleaned from these journals and meetings with students, with recommendations for future revision of the atrisk student initiative.

\section{Theoretical Framework}

The framework guiding this analysis at all levels is the Activity Theory (AT hereafter), which is a cross-disciplinary framework for studying how humans purposefully transform natural and social reality, including themselves, as an ongoing culturally and historically situated, materially and socially mediated process" (Roth, Radford and Lacroix 2012, p. 1). The unit of analysis in AT is the concept of object-oriented, collective and culturally mediated human activity system. AT was founded by Soviet psychologists Vygotsky, Lurija, Rubinstein and Leontev in the 1930s. Their idea was that activity was a fundamental philosophical and psychological concept because it was the essential notion in any viable philosophical anthropology.

When analysing human activity we must examine not only the kinds of activity that people engage in, but also who are engaging in that activity, what their goals and intentions are, what objects or products result from the activity, the rules and norms that circumscribe that activity, and the larger community in which the activity occurs.

When skills development is practiced in learning, it is not seen as the object of learning but as a means to better realize the learning process. Thus, based on the technological outlook of AT, individual functioning is considered to be distributed across and situated within the transaction of the contexts of the subject, available tools, and community with the division of labour (Liaw and Huang 2014). Since this analysis aimed to conduct an AT based enquiry into developing essential skills for college students in terms of student motivation, satisfaction, and learning 
effectiveness, it conceptualized an AT model to provide insights into learner perceptions of their own learning. The model looks at the activity as a purposeful, productive process carried out by subjects, who are at-risk students at the institution.

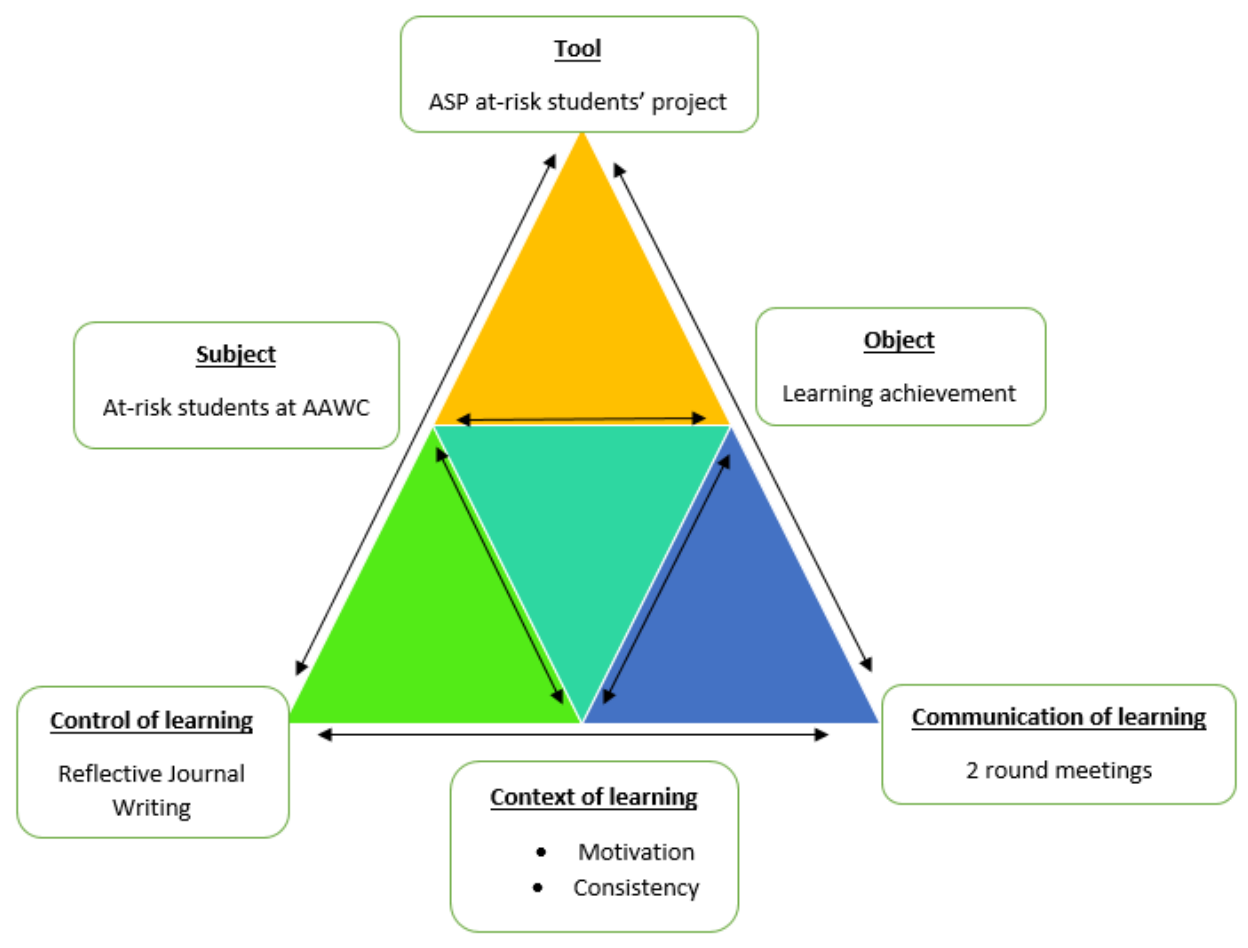

Figure 1: Activity Theory based model of at-risk students' learning achievement

The model looks at the activity as a purposeful, productive process carried out by subjects, who are at-risk students at the institution.

\section{Procedure}

The Academic Success Program (ASP) received the list of students who had GPA below 2.0.

The ASP team, which consisted of five tutors, met several times to discuss the ways to work with these students to assist in effective learning and adapted a questionnaire Essential Skills for College Students (Appendix A). The questionnaire consisted of six sections directed towards students' organization, study skills, respecting the rules and policies, stress management, assertiveness skills and a section for other problems causing academic difficulty, where students were given a chance to request to see a counselor. The last sixth section required the tutor and 
the student to choose three areas where the student needed improvement and work towards improving those skills.

The tutors sent the standardized email to all at-risk students asking for a meeting in two languages: English and Arabic (Appendix C). Then students got in touch with their tutors and booked an appointment for the first round meetings.

During these meetings the tutors discussed the questionnaire with students through growth mindset, that's to say encouraging students think about their thinking, learning, motivation, success and failures. After recording the areas to be improved the students then were asked to keep a reflective journal (Appendix B) for two weeks and see their tutors again. The students were asked to reflect upon the areas they needed to improve, the steps they took daily to reach their goals, their feelings and achievements.

After the first meeting, tutors put comments for students' advisors in the portal mentioning the outcomes of the meeting and the areas students agreed to work on. This was done to keep the advisors aware of the student-tutor meetings for further follow-ups, records, cooperation and assistance.

In two weeks the students received the second call and met the tutors to discuss their reflective journals. These journals then were collected for qualitative analysis.

Out of 140 at-risk students estimated number of first-round visits was 50 . The second-round meetings fall close to the final exam week therefore, only 21 students could come for the second meeting. Hence, this analysis are conducted on 21 student produced reflective journals.

\section{Ethical Considerations}

Ethical dilemmas lurk in any communication with people. To minimize the ethical problems this project followed Bryman and Bell's (2007) principles of ethical considerations.

- Project participants should not be subjected to harm in any ways whatsoever.

Neither students nor teachers were harmed in any way during the study. None of the participants complained about any aspect of the project being harmful for their life, learning or teaching. 
- Respect for the dignity of project participants should be prioritized.

All participant students were informed about the project through email in two languages (English and Arabic) before it commenced and the procedures were explained to them in details.

Their participation was not mandatory or forced and it was their decision to participate in the project. The participants' dignity was always prioritized and there were no issues recorded before, during and after the project that could affect their dignity in any way.

- The protection of the privacy of project participants has to be ensured.

This project kept the confidentiality of the discussions and details the students shared with the tutors. Students who requested a counselor and shared with their problems would be protected indefinitely.

- Adequate level of confidentiality of the project data should be ensured.

This project had absolutely no interest in linking the person as a unique, named individual to actual behaviour, and the data could be transferred to a coded, unnamed data sheet" (Cohen, Manion and Morrison 2007, p. 65). Therefore, the data in this project was number coded before being analysed.

- Affiliations in any forms, sources of funding, as well as any possible conflicts of interests have to be declared.

This project had no affiliations in any forms, nor was it funded by any organization. It was carried out in the workplace and had no conflicts of interest in any form.

\section{Results}

The actions leading to realize a task result in the achievement of the goal. Taking this into consideration the subcategories of the conceptual AT triangles illustrated in Figure 1 will be presented in loops to discuss the reflective journals in depth and find out results of actions in relation to the goal. 


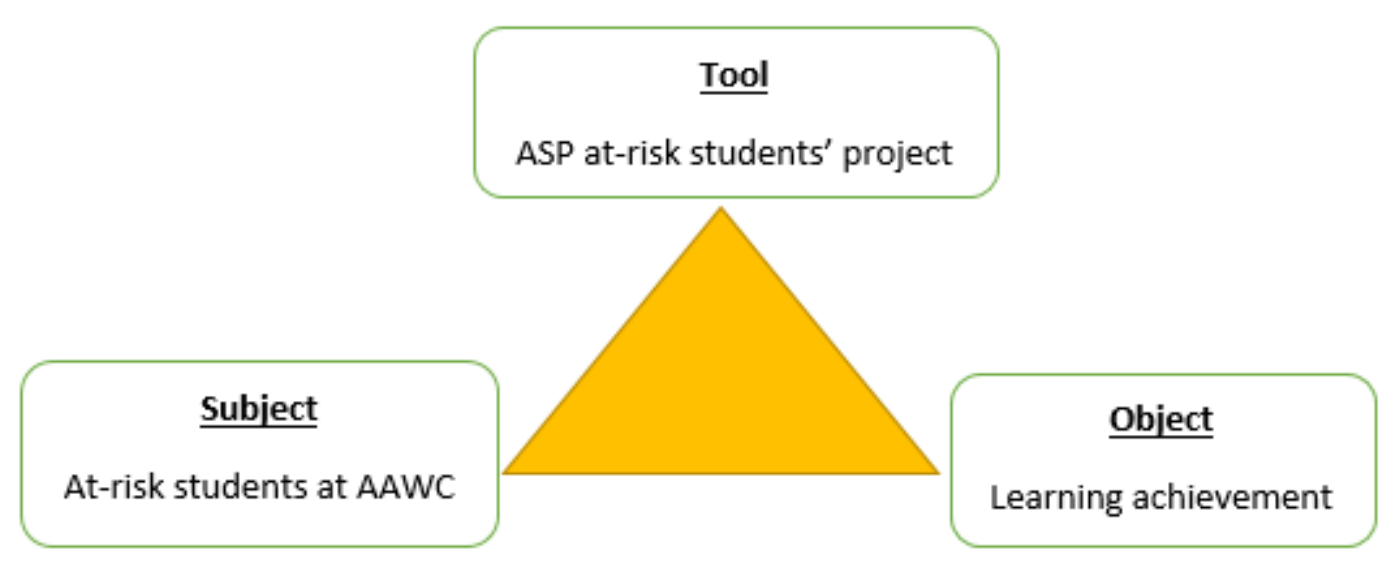

Figure 2: Tool, subject and object AT analysis

Figure 2 illustrates the AT analysis of the tool, subject and object interaction during the project. It conseptualizes the ways that the tool influences the subjects to reach the object.

Almost all students who wrote reflections mentioned the positive influence of ASP on their study behaviors. Some examples of their entries are the following:

- "I take notes about what teacher say for FWA. Before I asked my friends but now I do it myself. Why I didn't before? I don't know, it is helping me a lot. Thank you my ASP teacher", "I start to make a list of my assignments. Thank you this ws brilliant idea"

- "Went to the college ASP for extra classes in statistics. Thank you my tutor suggest this"

- "I use my phone once today. It was difficult but I promised my tutor"

- "I did vocab test and my score is good 42 out of 50. I study with tutor Shamma in library"

- "I meet with my teacher to view my project and discus it. I will do it all the time again"

As can be seen from the above mentioned journal entries, students expressed gratitude for assistance since they've noticed their own success. However, there is no evidence of further achievements from the third week onwards since the project ended there. So, we can say for confidence that the tool influenced positively the subjects to reach the object within two weeks. ASP at-risk students' meetings enabled collaborative interaction between tutors and students emphasising its influence on the students' learning practice, and consequently on their performance and achievement. 


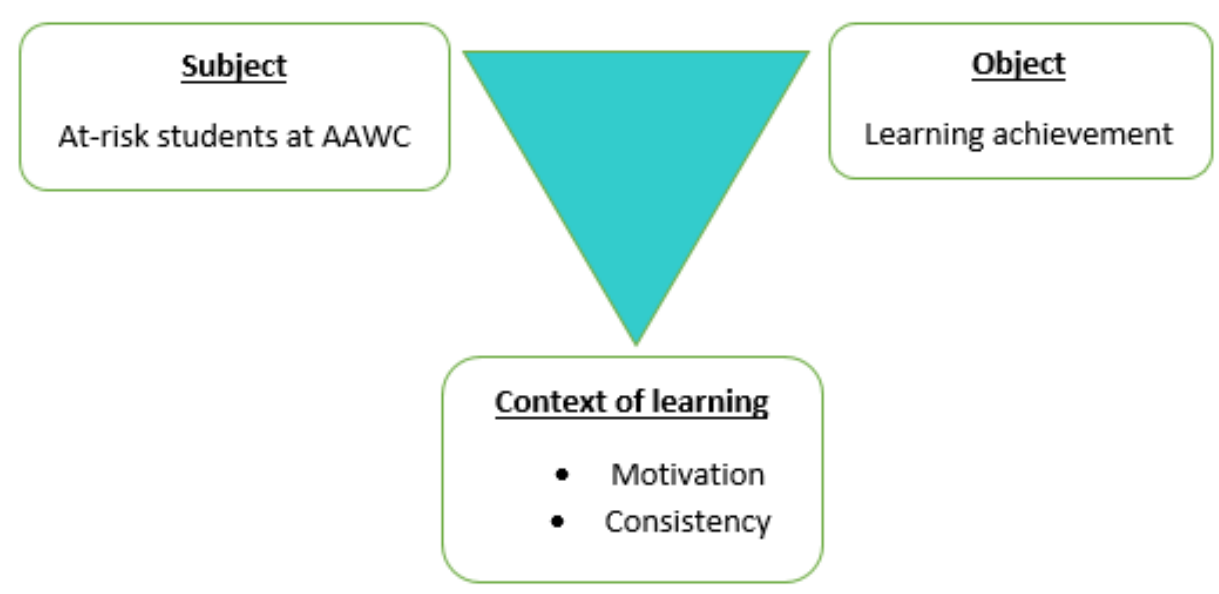

Figure 3: Subject, object and context of learning AT analysis

Figure 3 illustrates the interaction of subject, object and context of learning through AT analysis. The reflective journal coding revealed two core concepts: motivation and consistency, which became the context of learning. Therefore this section discusses the interrelations of subjects' motivation and consistency as contexts of learning towards learning achievement.

Throughout the journal entries the students mentioned about learning being promoted through motivation which encouraged their learning:

- "It is hard but I remember my tutor words and it is good for me"

- "I am happy I make study plan"

- "I came early to class today. My teacher said good for me. I will come early every day"

- "I try to be more serious in class and do not use my phone. My friend laugh at me but I remember my success tutor"

The positive student entries showed that tutor-student meetings initiated, guided and maintained goal-oriented behaviours. Students realized that simply having the desire to accomplish the learning tasks was not enough. Accomplishing those tasks required the ability and willingness to try and persist through technical obstacles and keep discovering and practicing in spite of anticipated and unanticipated learning challenges. A vivid example of motivation is when a student came after the second round meeting with a screenshot of her coursework grades happy that she was able to make it (Figure 4). 


\section{My Grades}

\begin{tabular}{|c|c|c|}
\hline Submitted & & Order by: Course Order \\
\hline ITEM & LAST ACTIVITY & GRADE \\
\hline $\begin{array}{l}\text { Toy Project Creation } \\
\text { DUE: APR 29, } 2018 \\
\text { Assignment }\end{array}$ & $\begin{array}{l}\text { May 1, } 2018 \text { 10:36 AM } \\
\text { GRADED }\end{array}$ & B \\
\hline $\begin{array}{l}\text { AS - Set Exercises } \\
\text { Grading Criteria }\end{array}$ & & B \\
\hline $\begin{array}{l}\text { Total } \\
\text { View Description Grading Criteria }\end{array}$ & & $\begin{array}{r}186.00 \\
/ 226\end{array}$ \\
\hline $\begin{array}{l}\text { Psycho social Development Presentation } \\
\text { DUE: FEB } 18,2018 \\
\text { Assignment } \\
\text { View Rubric }\end{array}$ & $\begin{array}{l}\text { Feb 19, } 2018 \text { 1:22 PM } \\
\text { GRADED }\end{array}$ & $\mathbf{B}+$ \\
\hline $\begin{array}{l}\text { EDU } 1003 \text { Quiz-Requires Respondus LockDown Browser } \\
\text { Test }\end{array}$ & $\begin{array}{l}\text { Feb 12, } 2018 \text { 12:27 PM } \\
\text { GRADED }\end{array}$ & $\begin{array}{r}\text { B- } \\
17 \\
\text { AVERAGE } \\
20 \\
\text { MEDIAN }\end{array}$ \\
\hline
\end{tabular}

Figure 4: Student's achievement

Another example of motivation is an email from a student to thank the tutor for help:

I really thank you for your support. I have achieved a lot of things after you talk with me, I really feel so happy and proud of my self this is thanks to God and then to you, now I can improve every thing because of you really really thank you ms?

\section{Thankyou,}

It can be stated that ASP tutor-student meetings and discussions through growth mindset method not only were satisfying for students, but also helped them understand and follow college rules to foster learning and accomplish tasks to accommodate their individual learning styles and needs. This, in its turn, developed a sense of competence in the students and motivated them intrinsically. 


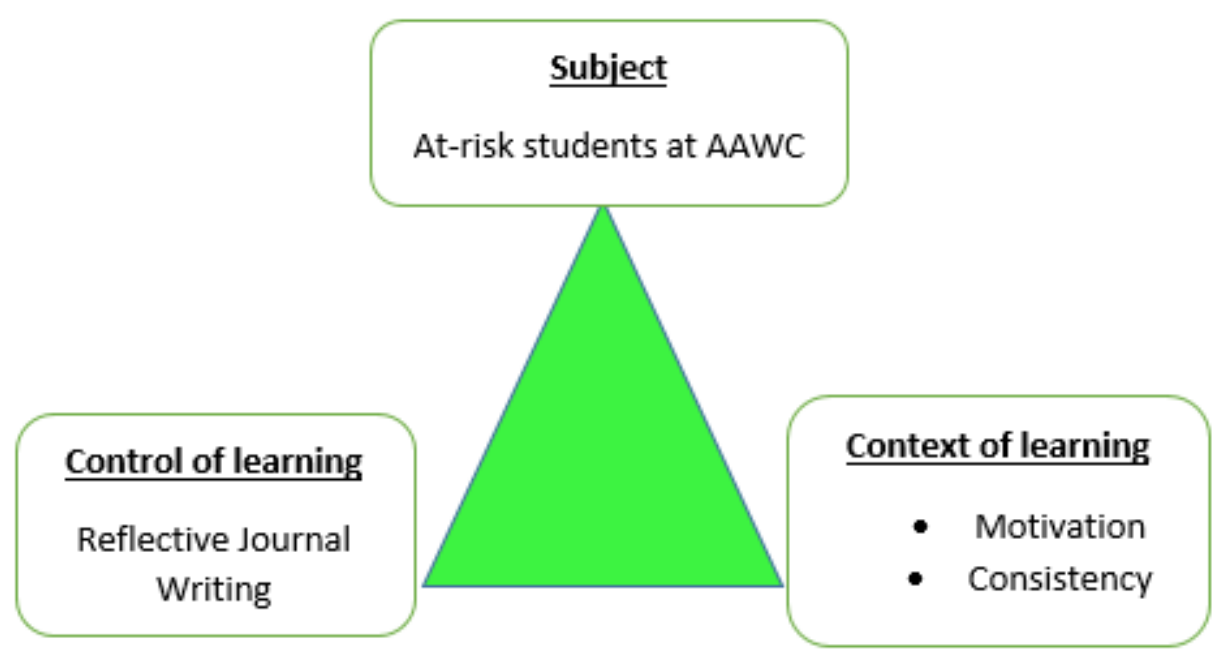

Figure 5: Subject, control of learning and context of learning AT analysis

Figure 5 illustrates the AT analysis of the effects that tutor-student meetings had on students' level of learning and motivation. The control of learning was writing reflections and steps taken to achieve the aim. The aim was to improve the three areas on "Essential Skills for College Students" (Appendix A) questionnaire that the tutor and the student discussed and chose three areas for the student to improve.

Reflective journals highlighted a firm connection between tutor-student meetings and the level of student motivation in learning. It was expressed through students' self-efficacy, self-regulation, perceived satisfaction and ASP usefulness to carry out learning tasks. Examples of student's selfefficacy, which supposes the level of student mastery of understanding college rules and regulations, were observed in their journals:

- "I start bring my charger to college"

- "I come to college on time"

- "I stop using my phone in class"

- "I study for finals"

- "Use my phone once today it was difficult to not use it and to study. But I tried."

Self-regulation, which supposes students' independent study skills recorded a high jump in their reflections throughout the two week period: 
- "I spend 2 hours today to study myself in ASP"

- "I did a new plan for studying and I feel confident that I did it"

- "I take notes what teacher say for FWA. My notes help me when I forget some things"

- "I take my laptop to IT to fix it for me. I feel I am becoming responsible student."

These positive and assertive feelings, skills and willingness to be in charge of their learning could not take students anywhere else but to motivation in their learning in terms of satisfaction and fulfillment.

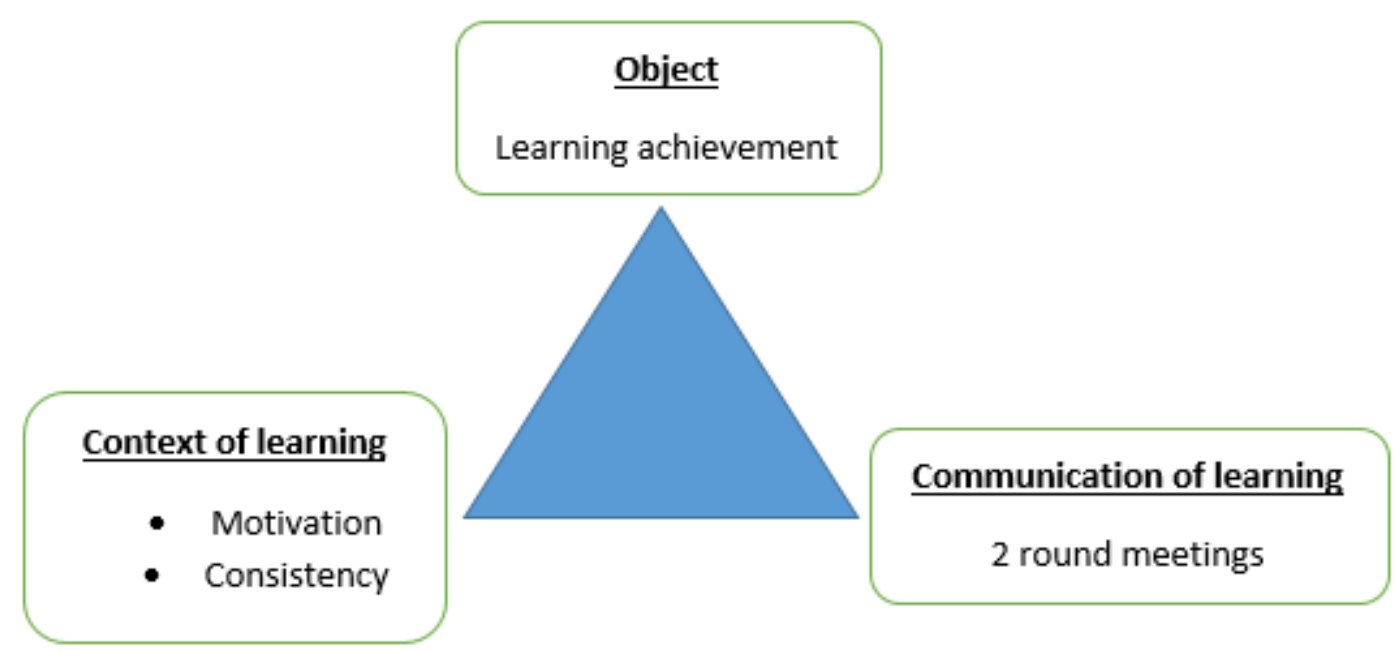

Figure 6: Object, context of learning and communication of learning AT analysis

Figure 6 explains the object, context of learning and communication of learning interrelations. Most of the popular theories about learning achievement are reinforced by the constructivist view, which means that there is no certain meaning of the world to comprehend, rather, there are various ways to structure that world and make meaning of it. Therefore, it is better to develop a learning environment for the learners to help to receive the material in a way that naturally fits their individual ways of constructing knowledge. While analyzing those reflective journals it is impossible not to notice multiple entries about time management, organizational skills and assertiveness skills being a spark for student motivation. Students' reflective journals not only talked positively in this regard but also connected it to learning effectiveness: 
- "I start to review my notes that I was wrote it. It make my study easy"

- "I prepare my self for final exams. I am not afraid to ask help from my teachers now. I think I

- '1l do good at final exam"

- "I put time for my study and it works very well for me because I start manage my time and I think I will get good marks",

- "I view my study plan and put a check mark for the things I have done"

- "I start eat healthy and feel my feeling and brain improve. I love to learn like this."

Now that all elements of activity theory have been looked at and discussed in loops, it is necessary to mention that the activity, which was undertaken by subjects using the tool to achieve the object, transformed it into an outcome and demonstrated positive results regardless of technical challenges. When students reflect, the value of reflections stem from the ways through which learning is achieved, whether students are able to develop study skills through growth mind set and whether they are able to control the learning speed and style of interaction. So, from the ASP perspective in learning, control of learning can be achieved based on learner characteristics such as self-efficacy and self-regulation, which, as students' reflections showed, can successfully result in motivation and active learning.

\section{Suggestions}

The results of this project suggest considerable potential for the ASP to facilitate students' motivation in learning. However, this project did not follow the aim of looking into specific ways of doing it. Another project could look into ways of student - tutor collaboration, peer-topeer interaction and engagement in learning by the help of ASP and offer new insights into how ASP can be incorporated into learning and what specific activities can boost student motivation, 21 century skills development and learning. In addition, it would be a major contribution to look at different ways of using advising to detect beneficial ways, attitudes and practices of boosting students' learning achievement.

This project was a pilot project which only lasted for two weeks. This time is not enough to manage to identify problems in depth and try to solve them as they arise. Therefore, it would be 
crucial to start working with at-risk students from the beginning of the semester until the end of it. It is important to collaborate with the advisors and course teachers not only by putting comments in the portal but also through face to face meetings with them and with the presence of students. This will result in in-depth collaboration and multivariate assistance directed toward the target student's learning achievement.

Because of lack of preparation and technical problems, this project was able to look at reflective journals only and conduct qualitative data analysis. To be able to triangulate the data it would be important to come up with ways to measure students' learning achievement through quantitative data analysis. Suggestion would be to compare students' GPAs at the beginning and at the end of the project. Another way would be to administer a fixed design questionnaire at the end of the project. Moreover, an experimental project having control and experimental groups of students would also fit the purpose.

\section{References}

Bryman, A. and Bell, E. (2007). Business Research Methods. London: Oxford University Press.

Cohen, L., Manion, L. and Morrison, K. (2007). Research Methods in Education. London and New York: Routledge,

Taylor and Francis Group.

Liaw, S. and Huang, H. (2014). Investigating Learner Attitudes toward e-books as Learning

Tools: Based on the Activity Theory Approach. Interactive Learning Environments. Vol. 10 (9), pp. 10-80.

Roth, W. M., Radford, 1. and LaCroix, L. (2012). Working With Cultural-Historical Activity Theory. Qualitative Social Research. Vol. 13 (2), pp. 1-15. 
Appendix A: Student-teacher meeting questionnaire

\section{Essential Skills for College Students}

The following are skills that will help you develop and be successful in college:

\section{Organization}

Organizational skills allow you to effectively plan, record, and organize your work.

\begin{tabular}{|l|l|l|}
\hline I have marked my exam dates my student calendar & $\mathrm{Y}$ & $\mathrm{N}$ \\
\hline I have marked my project due dates in my calendar & $\mathrm{Y}$ & $\mathrm{N}$ \\
\hline I have study times marked in my calendar & $\mathrm{Y}$ & $\mathrm{N}$ \\
\hline & & \\
\hline I have a folder for each course on my laptop & $\mathrm{Y}$ & $\mathrm{N}$ \\
\hline I have named each document with a title & $\mathrm{Y}$ & $\mathrm{N}$ \\
\hline I bring my charge to the college each day & $\mathrm{Y}$ & $\mathrm{N}$ \\
\hline I have MS Office and Lock Down Browser & $\mathrm{Y}$ & $\mathrm{N}$ \\
\hline & & \\
\hline I have a file for papers for each class & $\mathrm{Y}$ & $\mathrm{N}$ \\
\hline I bring everything I need to every class & $\mathrm{Y}$ & $\mathrm{N}$ \\
\hline
\end{tabular}

\section{Study Skills}

Knowing how to read a textbook, take notes in class, and prepare for exams are important skills.

I feel confident about taking notes

If I miss a class, I get the notes from a friend

I have a good plan for studying for exams.

\section{Respecting the Rules and Policies}

Rules make a positive community where all students are respectful of themselves, others and the environment.

\begin{tabular}{|l|l|l|}
\hline I am not late for classes & Y & $N$ \\
\hline I do not use my phone in class & Y & N \\
\hline I focus and do not chat, text or play in class & Y & N \\
\hline $\begin{array}{l}\text { If I am sitting next to a noisy girl, I will change my seat in the next } \\
\text { class }\end{array}$ & Y & N \\
\hline
\end{tabular}




\section{Stress Management}

Regular exercise, enough rest, and good nutrition are all ways of reducing stress. Finding ways to stay calm will help students decrease the stressors that life will throw your way.

\begin{tabular}{|l|l|l|}
\hline I go to bed before $11 \mathrm{pm}$ & $\mathrm{Y}$ & $\mathrm{N}$ \\
\hline I eat healthy food & $\mathrm{Y}$ & $\mathrm{N}$ \\
\hline I exercise 3x per week & $\mathrm{Y}$ & $\mathrm{N}$ \\
\hline
\end{tabular}

\section{Assertiveness Skills}

Speak up for yourself. Ask for help when you need it. Know how to confront a classmate nicely.

I feel confident asking my teachers for help

I can talk to a classmate if I have a problem with her

I will go to a tutor for extra help

\begin{tabular}{|l|l|}
\hline $\mathrm{Y}$ & $\mathrm{N}$ \\
\hline $\mathrm{Y}$ & $\mathrm{N}$ \\
\hline $\mathrm{Y}$ & $\mathrm{N}$ \\
\hline
\end{tabular}

\section{Choose three areas where you feel you need to improve.}

$\frac{1 .}{3 .}$

3.

Make a plan! How will you improve your skills?

Come back in one month Set a calendar appointment to meet with the Success Coordinator in one month to show how you have improved. This information will go to your advisor.

Adapted From

Clark University. (2018). Essential Skills for College Students. Retrieved from Clark University:

https://www.clarke.edu/campus-life/health-wellness/counseling/articles-advice/essential-skills-for-collegestudents/ 
Appendix B: Students' reflective journals

Journal for: Name ID

Keep notes of how you are improving your student skills.

The three areas I have agreed to work on are:

1.

2.

3.

Date:

What I did today:

Date:

What I did today: 
Date:

What I did today:

Date:

What I did today:

Appendix C: E-mail for at-risk students

Hello - Is your GPA below 2 ?

This is a very serious problem, and I want to help you improve your grades.

Here is what you have to do:

- You must meet with me in the Success Center to make a plan for improvement.

- Your advisor will get a copy of this plan, and add it to your file.

- You will have one month to work on this plan.

- Then, you will meet me again to talk about how you have improved.

- This information will also go into your advising file

Please make an appointment with me within two weeks in the Success Center (in the library, next to the graded readers). There is a sign-up sheet for appointments. 
I am looking forward to seeing you to think of good ways to help you improve your grades!

Make an appointment with

$$
\begin{aligned}
& \text { مرحبا، هل معدلك التر اكمي أقل عن 2؟ } \\
& \text { إنها مشكلة كبيرة و جدية و نحن نريد مساعدتك لتحسين درجاتك و أدائك الأكاديمي. } \\
& \text { إليك الخطوات التي يجب أن تتبعيها: } \\
& \text { يجب أن تأتي لمقابلتي في "مركز النجاح" لأتمكن من عمل خطة للك. } \\
& \text { مستشارك الأكاديمي سيحصل في على لائل نسخة من الخطة. } \\
& \text { ل لديك شهر واحد لاستكمال الخطة. } \\
& \text { يجب أن نأتي لمقابلتي بعد شهر واحد لاحد لنتحدث عن التحسن الأكاديمي الذي وصلتي له. } \\
& \text { هذه المعلومات ستوثق في ملفك الأكاديمي. } \\
& \text { يرجى منك الحصول على مو عد لمقابلتي في غضون أسبو عين في "مركز النجاح" في المكتبة. هناك ورقة تسجيل مو اعيد. } \\
& \text { نحن نتطلع لرؤينكم و مساعدتكم لتحسين مستو اكم الدر اسي و الأكاديمي. }
\end{aligned}
$$

